TITLE:

\title{
Monte Carlo Study of Vesicles
}

AUTHOR(S):

好村, 滋行; Baumgartner, A.

CITATION:

好村, 滋行 ...[et al]. Monte Carlo Study of Vesicles. 物性研究 1991, 57(3): 501-501

ISSUE DATE:

1991-12-20

URL:

http://hdl.handle.net/2433/94812

RIGHT: 


\title{
Monte Carlo Study of Vesicles
}

\author{
東工大理, KFA 好村滋行, A. Baumgärtner
}

自己排除体積効果を考虑した弾性的 (polymerized) 及び流体的 (fluid) な膜 (membrane) のモンテカルロシミュレーションを行った。弾性膜では、剛体球が一定長さ 以上に伸びない棒でっながれた三角形からなるネットワークをブラウニアンダイナ ミクスで動かした。また、流体膜ではネットワークの接続のつなぎかを許した。さ らに膜の edge の影響を取り除くために閉じた膜、すなわちべシクルを用いた。その 結果、弾性膜は異方性が残りクランプルしないことがわかった。これは高分子とは 著しく異なる振舞いである。すなわち弾性膜の慣性半径の 2 乗は膜の上のモノマー 数に比例して

$$
R^{2} \sim N^{\nu}
$$

とおけば $\nu \approx 1$ となる。一方流体膜では、モノマーは流動性を示し、 $\nu \approx 0.8$ となっ た [1]。

さらに弾性膜においてベシクルの内外の圧力差 $\Delta p$ を一定に保った場合のシミ レーションも行った。有限サイズスケーリングを使った解析の結果、 $\Delta p>0$ の場 合は表面のラフネスが減少し、いわゆるラフネス指数が 0.64 から 0 へ減少した。 $\Delta p<0$ の場合は $\nu$ が 1.0 から 0.66 へ減少することがわかった [2]。このように圧 力差が正と負とでは、クロスオーバーのおこりかたが全く異なってくる。

\section{参考文献}

[1] S. Komura and A. Baumgärtner, J. Phys. (Paris) 512395 (1990).

[2] S. Komura and A. Baumgärtner, to be published in Phys. Rev. A. 